\title{
Antiplasmodial and Cytotoxic Activities of Toad Venoms from Southern Amazon, Brazil
}

\author{
Felipe Finger Banfi', Karla de Sena Guedes', Carla Regina Andrighetti', Ana Carolina Aguiar², \\ Bryan Wender Debiasi ${ }^{3}$, Janaina da Costa Noronha ${ }^{3}$, Domingos de Jesus Rodrigues ${ }^{3}$, \\ Gerardo Magela Vieira Júnior ${ }^{4}$, Bruno Antonio Marinho Sanchez ${ }^{1, *}$
}

'Universidade Federal de Mato Grosso, Instituto de Ciências da Saúde, Sinop, MT, Brazil; 'Laboratório de Química Medicinal e Experimental, Universidade de São Paulo, São Carlos, SP, Brazil; ' Universidade Federal de Mato Grosso, Instituto de Ciências Naturais, Humanas e Sociais, Sinop, MT, Brazil; ${ }^{4}$ Universidade Federal do Piauí, Departamento de Química, Teresina, PI, Brazil

\begin{abstract}
The drug-resistance of malaria parasites is the main problem in the disease control. The huge Brazilian biodiversity promotes the search for new compounds, where the animal kingdom is proving to be a promising source of bioactive compounds. The main objective of this study was to evaluate the antiplasmodial and cytotoxic activity of the compounds obtained from the toad venoms of Brazilian Amazon. Toad venoms were collected from the secretion of Rhinella marina and Rhaebo guttatus in Mato Grosso State, Brazil. The powder was extracted at room temperature, yielding 2 extracts (RG and RM) and a substance ('1') identified as a bufadienolide, named telocinobufagin. Growth inhibition, intraerythrocytic development, and parasite morphology were evaluated in culture by microscopic observations of Giemsastained thin blood films. Cytotoxicity was determined against HepG2 and BGM cells by MTT and neutral red assays. The 2 extracts and the pure substance ('1') tested were active against chloroquine-resistant Plasmodium falciparum strain, demonstrating lower $\mathrm{IC}_{50}$ values. In cytotoxic tests, the 2 extracts and substance ' 1 ' showed pronounced lethal effects on chloroquine-resistant $P$. faciparum strain and low cytotoxic effect, highlighting toad parotoid gland secretions as a promising source of novel lead antiplasmodial compounds.
\end{abstract}

Key words: Plasmodium falciparum, antiplasmodial effect, toad venom, bufadienolide, malaria chemotherapy

\section{INTRODUCTION}

The 2015 Nobel Prize in Physiology or Medicine was awarded to 3 scientists who made pioneering discoveries of drugs currently used to treat neglected tropical diseases [1]. A portion of the award was to Youyou Tu (China), guided by ancient Chinese texts, isolated a component from the plant Artemesia annua, called artemisinin, which proved to be highly effective against the malaria parasite [2]. Artemisinin has now become the drug of choice for the treatment of malaria throughout most of the tropical world.

Malaria remains an important cause of illness and death in children and adults in underdeveloped countries in which it is endemic. The drug-resistant malaria parasite is the main prob-

\footnotetext{
- Received 1 March 2016, revised 3 May 2016, accepted 26 May 2016.

*Corresponding author (bamsanchez@hotmail.com)

(C) 2016, Korean Society for Parasitology and Tropical Medicine

This is an Open Access article distributed under the terms of the Creative Commons

Attribution Non-Commercial License (http://creativecommons.org/licenses/by-nc/4.0) which permits unrestricted non-commercial use, distribution, and reproduction in any

medium, provided the original work is properly cited.
}

lem in the disease control. Artemisinin resistance has been described in malaria endemic areas, threatening malaria control, treatment, and elimination efforts worldwide [3]. World Health Organization (WHO) updated their treatment policy in countries where P. falciparum parasite is endemic from use of monotherapy with drugs such as chloroquine, amodiaquine, and sulfadoxine-pyrimethamine (SP) to currently recommended artemisinin-based combination therapies (ACT) [4]. However, resistance to ACTs has arisen recently in $P$. falciparum in South East Asia [4,5]. Therefore, it is necessary to develop novel drugs for malaria therapy, particularly in regions where resistant Plasmodium strains are present.

The use of natural products has provided a prospective strategy for identifying novel antimalarial drugs. In this context, the bioprospecting of secondary metabolites can be an important tool to new antimalarial drugs discovery. The use of animals, plants, fungi, and bacteria are important sources of biologically active substances with structural diversity and novel mechanisms of action, which can possibly provide patentable products [6-12]. An example is the development of Captopril ${ }^{\circledR}$, 
this medicine was based on research on small peptides from the venom of the South American snake (Bothrops jararaca) that were known to potentiate the action of bradykinin [13-15].

In the class of Amphibians are the family Bufonidae that possesses about 471 species [16]. An important genus of this family is Rhinella (formerly Bufo in the New World), which consists of about 258 species. In Latin America, they are found in Amazon regions of Brazil, Bolivia, Colombia, Peru, Suriname, Guiana, and Venezuela [17]. The skin secretions and venom of amphibians are rich sources of bioactive compounds, such as peptides, alkaloids, bufadienolides, biogenic amines, and proteins. These molecules play a crucial role in the physiological functions of these animals, especially for predation and protection against microorganisms [18,19]. Previous studies with Rhinella marina venom resulted in the identification by LC-MS of the 4 bufadienolides; telocinobufagin, marinobufagin, bufalin, and resibufogenin, and in Rhaebo guttatus venom marinobufagin was identified [20]. Bufadienolides are an important group of steroid hormones that has shown vasoconstriction [21], antiviral [22,23], antitumoral [24-26], cytotoxic [8,20,27,28], antileishmanial, and antitrypanosomal activities [29].

The potential of natural products to provide the development of antimalarial compounds is evident [30]. Animals contain a large assortment of structurally unique secondary metabolites that can be useful as new chemical templates for drug discovery $[6,8]$. Although amphibian skin secretions have proved to be a rich source of exclusive molecules, no studies have evaluated the potential antimalarial activity of these compounds. Our objectives were to conduct bioprospecting of the extracts and pure compound from R. marina (synonymy Bufo marinus) and $R$. guttatus toad venom, occurring in the Southern Amazon of Mato Grosso, Brazil, with antiplasmodial and cytotoxic activities against tumor and normal cells lines.

\section{MATERIALS AND METHODS}

\section{Sample collection}

Toad venoms were collected from the secretion of $R$. marina and $R$. guttatus in Mato Grosso State, Brazil. The animals were identified by one of the authors (D. J. Rodrigues, IBAMA, SISBIO: no. 30034-1). Voucher specimens (R. marina ABAM-H 1262 and R. guttatus ABAM-H 1538) were deposited in the Acervo Biológico da Amazônia Meridional (Sinop, Mato Grosso, Brazil).

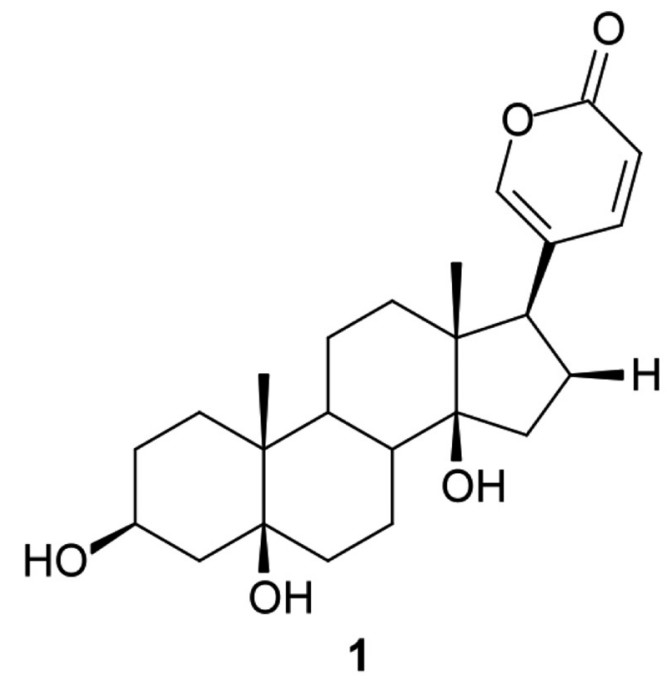

Fig. 1. Chemical structure of ' 1 ', telocinobufagin.

\section{Extraction and isolation}

Samples of toad venoms of $R$. marina and $R$. guttatus were dried, powdered, and extracted 3 times $\left(5 \mathrm{ml}\right.$ ) with $\mathrm{CHCl}_{3} /$ $\mathrm{MeOH}$ by ultrasonication for $10 \mathrm{~min}$ at room temperature [20]. The extracts were identified by the following codes: RM (R. marina) and RG (R. guttatus). The extract (1.1 g) from $R$. marina venom was chromatographed on Sephadex LH-20 column (GE Healthcare, Freiburg, Germany) using $\mathrm{MeOH}$ as eluent. The subfraction 140 yielded the compound ' 1 ' (25.7 mg). The compound '1' (Fig. 1) was identified by spectrometric methods (mass, NMR ${ }^{1} \mathrm{H}$ and ${ }^{13} \mathrm{C}$ ) and by comparison with literature [18], as a bufadienolide, named telocinobufagin.

\section{Parasites}

Chloroquine (CQ)-resistant W2 strain of P. falciparum was used for in vitro blood stage culture to test the antiplasmodial efficacy of toad venom extracts and ' 1 '. P. falciparum continuous culture was maintained according to the method described previously [31] with minor modifications. Cultures were maintained at $5 \%$ hematocrit using type $\mathrm{O}^{+}$human erythrocytes in RPMI 1640 medium (Sigma-Aldrich, St. Louis, Missouri, USA) supplemented with $25 \mathrm{mM} \mathrm{NaHCO}_{3}$, 1.0\% albumax, 45 $\mathrm{mg} / \mathrm{L}$ hypoxanthine, $40 \mu \mathrm{g} / \mathrm{ml}$ gentamycin and incubated at $37^{\circ} \mathrm{C}$ under approximately $5 \%$ of $\mathrm{CO}_{2}$. The parasites were synchronized at ring stage by sorbitol treatment [32]. Initial parasitemia was adjusted to $0.5 \%$ with $2 \%$ hematocrit in experiments. 


\section{Antiplasmodial activity}

Growth inhibition of intraerythrocytic forms and parasite morphology were evaluated in culture by the microscopic observation of Giemsa-stained thin blood films. After synchr onization by sorbitol treatment, parasite culture at ring stage ( $0.5 \%$ parasitemia and $2 \%$ hematocrit) was added to each well of 96-well microculture plates. The toad venom extracts (RG and $\mathrm{RM}$ ) and ' 1 ' were dissolved in DMSO and diluted to appropriate concentrations using complete medium $(10 \mathrm{mg} / \mathrm{ml})$ and stored at $4^{\circ} \mathrm{C}$. The final concentration in the culture was $1 \%$. After incubation at $37^{\circ} \mathrm{C}$ for $48 \mathrm{hr}$, P. falciparum growth inhibition was assessed by Giemsa-stained smears by observing 5,000 erythrocytes per 1 thin blood film in triplicate. The culture medium was replaced with fresh medium with or without test samples/control drugs. Chloroquine (CQ) was used as a reference antimalarial. The activity of the extracts and ' 1 ' was expressed as the percentage reduction in parasitemia relative to controls without drugs. All experiments were performed in triplicate. The results were expressed as the mean of the $\mathrm{IC}_{50}$ (the lethal drug concentration that reduced parasite viability in $50 \%$ ).

\section{Cells culture to cytotoxic assays}

The cytotoxicity testing was performed in 2 cell lines; human hepatoma cells (HepG2) and normal kidney glomerular cells (BGM). Both of these cell lines were cultured in $75 \mathrm{~cm}^{2}$ sterile flasks. RPMI 1640 (Sigma-Aldrich, St. Louis, Missouri, USA) medium supplemented with $10 \%$ heat-inactivated fetal calf serum and $40 \mathrm{mg} / \mathrm{L}$ gentamycin in a $5 \% \mathrm{CO}_{2}$ atmosphere at $37^{\circ} \mathrm{C}$. When confluent, the cell monolayer was washed with culture medium, trypsinized, distributed in a flat-bottomed 96 well plate $\left(5 \times 10^{3}\right.$ cells/well $)$, and incubated for $18 \mathrm{hr}$ at $37^{\circ} \mathrm{C}$ for cell adherence [33]. The compounds (20 $\mu$ l) were diluted to various Log concentrations $(0.2-200 \mu \mathrm{g} / \mathrm{ml})$ and incubated with the cells for $24 \mathrm{hr}$ in a $5 \% \mathrm{CO}_{2}$ atmosphere at $37^{\circ} \mathrm{C}$.

\section{Cytotoxic activity}

A 3-(4,5-dimethylthiazol-2-yl)-2,5-diphenyltetrazolium bromide (MTT) solution ( $5 \mathrm{mg} / \mathrm{ml} ; 20 \mu \mathrm{l} /$ well) was added to evaluate mitochondrial viability; after a further $3 \mathrm{hr}$ incubation, the supernatants were carefully removed, $100 \mu$ of DMSO was added to each well, and the reactions were mixed to solubilize the formazan crystals. The optical density was determined at $540 \mathrm{~nm}$ to measure the signal and background, respectively (Spectra Max340PC ${ }^{384}$, Molecular Devices, Sunnyvale, California, USA). The cell viability was expressed as a per- centage of the control absorbance in the untreated cells after subtracting the appropriate background.

The neutral red assay (NR) [34] was also performed in triplicate. After addition of the samples and $3 \mathrm{hr}$ incubation, the supernatants were carefully removed and $200 \mu \mathrm{l}$ of neutral red solution $(40 \mu \mathrm{g} / \mathrm{ml})$ were added to each well. The microplates were incubated again at $37^{\circ} \mathrm{C}$ in a humidified atmosphere with $5 \% \mathrm{CO}_{2}$ for $3 \mathrm{hr}$. Then, the supernatant was removed and added to $200 \mu \mathrm{l}$ of formaldehyde solution $(0.5 \%, \mathrm{v} / \mathrm{v})$ and $\mathrm{CaCl}_{2}$ (1\%) to each well of the test plate. After $5 \mathrm{~min}$, the supernatant was again removed, and $100 \mu \mathrm{l}$ acid alcohol solution $(50 \%, \mathrm{v} / \mathrm{v}$ ethanol in $1 \% \mathrm{v} / \mathrm{v}$ acetic acid) were added to each well. The absorbance of the microplate was read in an ELISA reader (Spectra Max340PC ${ }^{384}$, Molecular Devices, Sunnyvale, California, USA) using $540 \mathrm{~nm}$ filter.

The minimum lethal dose for $50 \%$ of the cells $\left(\mathrm{LD}_{50}\right)$ was determined as described [35]. RM and RG extracted compounds, ' 1 ', and chloroquine concentrations used to calculate $\mathrm{LD}_{50}$ were $2-2,000 \mu \mathrm{g} / \mathrm{ml}$.

\section{Selectivity index (SI)}

A selectivity index (SI) corresponding to the ratio between the cytotoxic and antiparasitic activities of each sample tested. The values greater than 10 were considered indicative of lack of toxicity; however, the substances with values below 10 were considered toxic [36]. The SI index was calculated as follow: $\mathrm{SI}=\mathrm{LD}_{50}$ Cell $/ \mathrm{IC}_{50} P$. falciparum.

\section{Statistical analysis}

The concentrations of compounds able to inhibit $50 \%$ of parasite growth $\left(\mathrm{IC}_{50}\right)$ were determined based on the equation of the curve obtained by plotting the $\%$ of parasitemia regression vs the log of the concentration of compound. The coefficients of regression of these curves were calculated using the method of least squares. The $\mathrm{LD}_{50}$ were determined based on the equation of the curve obtained by plotting the $\%$ of cellular death versus the concentration of compound (GraphPad Prism Software ${ }^{\circ}$, version 5.0 for Windows, San Diego, California, USA). The average $\mathrm{IC}_{50}$ and $\mathrm{LD}_{50}$ were compared using ANOVA. Statistical significance was defined at the $5 \%$ level $(P<0.05)$.

\section{RESULTS}

In vitro anti-plasmodial activity

The extracts RG, RM, and '1' diluted in DMSO were assayed 
for antiplasmodial activity against chloroquine-resistant $P$. falciparum W2. Table 1 shows the antiplasmodial activity of RG, $R M$, and ' 1 ' in 2 different experiments. When evaluated the venom extracts and ' 1 ' in concentrations of $100 \mu \mathrm{g} / \mathrm{ml}$, all of them showed the parasitemia reduction above $60 \%$. The compound ' 1 ' showed and high potential of parasitemia reduction in vitro and the lower standard deviation (Fig. 2). Despite the high reduction of parasitemia of compound ' 1 ', RG extract had a lower $\mathrm{IC}_{50}$ value. Starting from $100 \mu \mathrm{g} / \mathrm{ml}$, the compounds were diluted to various concentrations (0.78-100 $\mu \mathrm{g} / \mathrm{ml}$ ) to calculate the $\mathrm{IC}_{50}$ values. All samples $(\mathrm{RG}, \mathrm{RM}$, and ' 1 ') showed values lower than $2 \mu \mathrm{g} / \mathrm{ml}$, thus considered active against $P$. falciparum $\mathrm{W} 2$ strain (Fig. 3).

\section{Cytotoxic activity on HepG2 and BGM cells}

To evaluate the cytotoxic activity of the extracts and compound ' 1 ', cytotoxic assays were performed by MTT and neutral red assays in human hepatoma cells (HepG2) and normal kidney glomerular cells (BGM). When analyzed the cytotoxic activity of the samples by MTT assay in HepG2 cells, it was observed that all samples (RG, RM, and ' 1 ') showed high $\mathrm{LD}_{50}$ values, being low or not cytotoxic to this cell line $(57 \sim>100 \mu \mathrm{g} / \mathrm{ml}$ ) (Table 1). In MTT assay in BGM cells, RG extract showed $\mathrm{LD}_{50}$ values of $34.8 \mu \mathrm{g} / \mathrm{ml}$. This value to RG extract can be considered low cytotoxic to BGM cells. The other extracts (RM and '1')

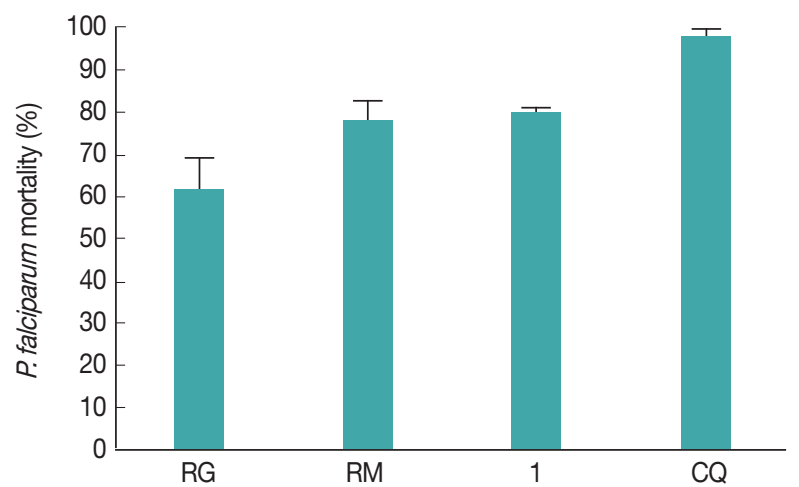

Fig. 2. Parasitemia reduction (\%) of $P$. falciparum W2 strain showing the mean $\pm \mathrm{SD}$ of the $\mathrm{RG}, \mathrm{RM}$, and ' 1 ' compound. $\mathrm{RM}, R$. marina; RG, R. guttatus; ' 1 ', telocinobufagin at a concentration of $100 \mu \mathrm{g} / \mathrm{ml}$; CQ, chloroquine, the antimalarial used as the positive control at a concentration of $100 \mu \mathrm{g} / \mathrm{ml}$.

Table 1. $I C_{50}, L D_{50}$, and SI values obtained from in vitro tests with extracts (RG and $\left.R M\right), 1$ obtained from toads venom, and chloroquine (CQ) against $P$. falciparum W2 strain

\begin{tabular}{|c|c|c|c|c|c|c|c|c|c|c|}
\hline \multirow{3}{*}{ Samples } & \multicolumn{2}{|c|}{$\mathrm{IC}_{50}$} & \multicolumn{4}{|c|}{$L D_{50}{ }^{a}$} & \multicolumn{4}{|c|}{$\mathrm{Sl}^{\mathrm{a}}$} \\
\hline & \multirow{2}{*}{ Value ( $\mu \mathrm{g} / \mathrm{ml})$} & \multirow{2}{*}{$\mathrm{R}$} & \multicolumn{2}{|c|}{ MTT } & \multicolumn{2}{|c|}{ NR } & \multicolumn{2}{|c|}{ MTT } & \multicolumn{2}{|c|}{ NR } \\
\hline & & & HepG2 & BGM & HepG2 & BGM & HepG2 & BGM & HepG2 & BGM \\
\hline$R G$ & 0.050 & 0.5247 & 109.91 & 34.83 & $>100$ & 22.62 & $>2,000$ & $>500$ & $>100$ & $>100$ \\
\hline $\mathrm{RM}$ & 0.534 & 0.9396 & 57.00 & 38.90 & $>200$ & $>200$ & 72.84 & $>100$ & $>100$ & $>100$ \\
\hline 1 & 1.280 & 0.9646 & 102.16 & 133.86 & $>200$ & $>200$ & 84.50 & $>100$ & $>100$ & $>100$ \\
\hline $\mathrm{CQ}^{\mathrm{b}}$ & 0.234 & 0.9894 & $>1,000$ & $>1,000$ & $>1,000$ & $>1,000$ & $>1,000$ & $>1,000$ & $>1,000$ & $>1,000$ \\
\hline
\end{tabular}

${ }^{a} \mathrm{LD}_{50}$ and SI values were obtained with MTT and neutral red (NR) cytotoxic tests in human hepatoma cells (HepG2) and normal kidney glomerular cells (BGM).

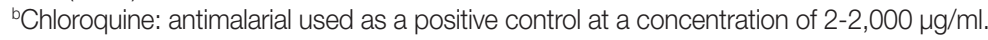
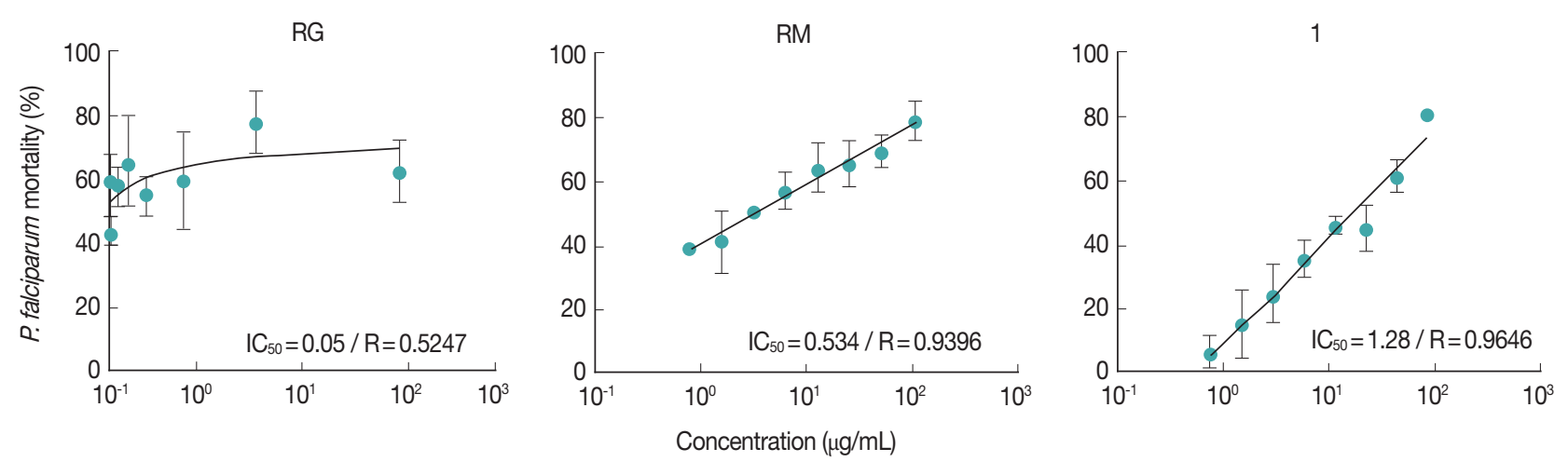

Fig. 3. Dose-response curves of RM, RG, and ' 1 ' in function of linear regression. Effects of different concentrations of RM, RG, and ' 1 ' $(0.78-100 \mu \mathrm{g} / \mathrm{ml})$ on the activity of $P$. falciparum W2 strain. Each point represents the mean $\pm \mathrm{SD}$ of 2 different samples performed in triplicates. $I \mathrm{C}_{50}$ values are presented in graphic. 
showed high $\mathrm{LD}_{50}$ values (38.9 > $100 \mu \mathrm{g} / \mathrm{ml}$ ), not being cytotoxic to BGM cells.

When the cytotoxic activity of the samples was analyzed in the neutral red assay, it was observed that all compounds showed high $\mathrm{LD}_{50}$ values in both the cell line HepG2 and is therefore considered not cytotoxic. In BGM cells, the RG showed $\mathrm{LD}_{50}$ values of $22.6 \mu \mathrm{g} / \mathrm{ml}$ (Table 1 ).

Evaluating the selectivity index (SI), all compounds showed high selectivity for the parasites when analyzed by MTT assay in the HepG2 cells (SI> 72.8). In BGM lineage, it was observed SI $>100$ for the all compounds tested. In neutral red assays, all samples showed high selectivity for the parasites when analyzed in HepG2 e BGM cells (> 100) (Table 1).

\section{DISCUSSION}

Several extensive molecules and natural products screens against $P$. falciparum blood stages have been published annually, emerging as new candidates for antimalarial drugs. However, no antiplasmodial activity of molecules and aqueous and organic extracts obtained from toad skin glands, whose secretions exhibit bufadienolides, was previously described.

Secretions from 2 toad species, R. marina and R. guttatus, were chemically investigated previously, and the isolation of telocinobufagin was described in $R$. marina venom [20]. When analyzed the $\mathrm{IC}_{50}$ values of extracts and compound ' 1 ' from the toad venoms, it was noted that all samples showed values lower than $5 \mu \mathrm{g} / \mathrm{ml}$ can be considered highly active against $P$. falciparum W2 strain. According to WHO guidelines and studies by Pink et al. [37], the rating for the antimalarial activity of a drug is as follows: highly active $\left(\mathrm{IC}_{50}<5 \mu \mathrm{g} / \mathrm{ml}\right)$, promising active $(5-15 \mu \mathrm{g} / \mathrm{ml})$, lowest active $(15-50 \mu \mathrm{g} / \mathrm{ml})$, and inactive ( $>50 \mu \mathrm{g} / \mathrm{ml}$ ).

The telocinobufagin (' 1 ') showed a high reduction of parasitemia in vitro. One study demonstrated the biological activity of steroids telocinobufagin and hellebrigenin against Leishmania chagasi promastigotes, but only hellebrigenin was active against Trypanosoma cruzi trypomastigotes [29]. Ferreira et al. [20] showed the differences in composition between $R$. marina and R. guttatus venoms, in terms of the number and type of constituents. The telocinobufagin is found only in R. marina venom, together with another 3 bufadienolides: marinobufagin, bufalin, and resibufogenin. However, only bufadienolide (marinobufagin) was identified in $R$. guttatus venom. Thus, the lowest $\mathrm{IC}_{50}$ value in antiplasmodial test can be explained by the presence of only on bufadienolide in the constitution of R. guttatus venom. This suggests a synergistic effect of bufadienolides present in R. marina venom.

Venom extracts from R. marina and R. guttatus showed moderate cytotoxic activities against HepG2 and BGM cells in MTT assay, respectively. Besides, when the cytotoxic activity of the extracts was analyzed by neutral red assay, it was observed that all samples showed high $\mathrm{LD}_{50}$ values in the HepG2 cells, and RG showed moderate cytotoxicity in BGM cells. A study in seaweed in northeastern Brazil showed greater susceptibility of BGM cells to crude extracts of the studied algae when compared to macrophages [37]. However, in our study, the purified substance telocibufaginin did not show cytotoxic activities for cell line HepG2. The low cytotoxicity of the telocinobufagin against cancer cell lines (HL-60, SF-295, MDA-MB-435, and HCT-8) was demonstrated in bufadienolides isolated from the Brazilian toad Rhinella schneideri [8].

In our study, antiplasmodial and cytotoxic activities in HepG2 cells were best observed in RG extract. The presence of 4 bufadienolides in RM extract displayed less in vitro efficacy against $P$. falciparum compared to the RG extract. These results differ from previous studies that have reported a higher cytotoxic activity of venom extracts from $R$. marina in comparison to those from $R$. guttatus due the presence of 3 other bufadienolides (telocinobufagin, bufalin, and resibufogenin), as well as marinobufagin, only bufadienolide identified in R. guttatus venom [20].

According to Bézivin et al. [36], values higher than 10 (SI> $10)$ is indicative of high selectivity values, whereas values below $10(\mathrm{SI}<10)$ are considered as low selectivity. In this study, for all tested samples (RG, RM, and ' 1 '), the SI was considered as high selectivity. The high selectivity index of the extracts and '1' indicate either an absence or large difference in the structure of the target molecule between $P$. falciparum and the mammalian cell. Therefore, these extracts could be exploited to identify the molecular target, which subsequently could be helpful to design novel therapeutics to combat malaria.

In this work, it was important to assess the cytotoxic activity of extracts and pure compound ' 1 ' in 2 different cell lines; tumoral and non-tumoral cells. An important article showed recently that the same chemical agent or compound can have different mechanisms of action in the cells when tested in different cell types [39]. The RM and ' 1 ' compounds did not have the $\mathrm{LD}_{50}$ values determined in BGM cells used in both cytotoxic assays. Thus, it can be suggested that the mechanism of ac- 
tion of these compounds in BGM cells can be different from HepG2 cells. These results demonstrate the importance of the cytotoxicity test and calculating the selectivity index for natural products with possible antimalarial activity. If only $\mathrm{IC}_{50}$ values for parasite were analyzed, it may be concluded that all the samples would have potential antimalarial acticities. In a study by Cenzi [40] to assess the antimalarial activity of sulfonamides derived from 4-metoxichalcona, all molecules were considered highly active against $P$. falciparum W2. However, when analyzing the selectivity index values of sulfonamides derived from 4-metoxichalcona, it was concluded that none of molecules was considered to have high selectivity for the parasites.

In summary, all assayed samples (extracts and ' 1 ') showed antiplasmodial activity. The extracts of $R$. marina and $R$. guttatus venoms and ' 1 ' isolated compound from $R$. marina showed pronounced lethal effects in $P$. faciparum chloroquine-resistant strain, highlighting toad parotoid gland secretions as a promising source of novel lead antimalarial compounds. The compound ' 1 ' can serve as a prototype molecule for the development of more active compounds.

\section{ACKNOWLEDGMENT}

This work was financially supported by the $\mathrm{CNPq}$ (Conselho Nacional de Desenvolvimento Científico e Tecnológico, Brazil) and FAPEMAT (Fundação de Amparo à Pesquisa do Estado de Mato Grosso, Brazil).

\section{CONFLICT OF INTEREST}

The authors declare no conflict of interest.

\section{REFERENCES}

1. McKerrow JH. Recognition of the role of natural products as drugs to treat neglected tropical diseases by the 2015 Nobel Prize in physiology or medicine. Nat Prod Rep 2015; 32: 1610-1611.

2. Tu YY, Liang XT. Studies on the constituents of Artemisia annua. Acta Pharma Sin 1981; 16: 366-369 (in Chinese).

3. Ashley EA, Dhorda M, Fairhurst RM, Amaratunga C, Lim P, Suon S, Sreng S, Anderson JM, Mao S, Sam B, Sopha C, Chuor CM, Nguon C, Sovannaroth S, Pukrittayakamee S, Jittamala P, Chotivanich K, Chutasmit K, Suchatsoonthorn C, Runcharoen R, Hien TT, Thuy-Nhien NT, Thanh NV, Phu NH, Htut Y, Han KT, Aye KH, Mokuolu OA, Olaosebikan RR, Folaranmi OO, Mayxay M, Khanthavong M, Hongvanthong B, Newton PN,
Onyamboko MA, Fanello CI, Tshefu AK, Mishra N, Valecha N, Phyo AP, Nosten F, Yi P, Tripura R, Borrmann S, Bashraheil M, Peshu J, Faiz MA, Ghose A, Hossain MA, Samad R, Rahman MR, Hasan MM, Islam A, Miotto O, Amato R, MacInnis B, Stalker J, Kwiatkowski DP, Bozdech Z, Jeeyapant A, Cheah PY, Sakulthaew T, Chalk J, Intharabut B, Silamut K, Lee SJ, Vihokhern B, Kunasol C, Imwong M, Tarning J, Taylor WJ, Yeung S, Woodrow CJ, Flegg JA, Das D, Smith J, Venkatesan M, Plowe CV, Stepniewska K, Guerin PJ, Dondorp AM, Day NP, White NJ. N Engl J Med 2014; 371: 786

4. World Health Organization. World Malaria Report: WHO Press; 2014 [cited 2015 March] 2014. Available: http://www.who.int/ malaria/publications/world_malaria_report_2014/en/.

5. Fairhurst RM. Understanding artemisinin-resistant malaria: what a difference a year makes. Curr Opin Infect Dis 2015; 28: $417-$ 425.

6. Rocha AB, Lopes RM, Schwartsmann G. Natural products in anticancer therapy. Curr Opin Pharmacol 2001; 1: 364-369.

7. Clardy J, Walsh C. Lessons from natural molecules. Nature 2004; 432: 829-837.

8. Cunha-Filho GA, Resck IS, Cavalcanti BC, Pessoa CO, Moraes MO, Ferreira JR, Rodrigues FA, Dos Santos ML. Cytotoxic profile of natural and some modified bufadienolides from toad Rhinella schneideri parotoid gland secretion. Toxicon 2010; 56: 339-348.

9. Ferreira PMP, Costa-Lotufo LV, Moraes MO, Barros FWA, Martins AMA, Cavalheiro AJ, Bolzani VS, Santos AG, Pessoa C. Folk uses and pharmacological properties of Casearia sylvestris: a medicinal review. Anais Acad Bras Cienc 2011; 83: 1373-1384.

10. Ferreira PMP, Farias DF, Viana MP, Souza TM, Vasconcelos IM, Soares BM, Pessoa C, Costa-Lotufo LV, Moraes MO, Carvalho AFFU. Study of the antiproliferative potential of seed extracts from Northeastern Brazilian plants. Anais Acad Bras Cienc 2011; 83: 1045-1058.

11. Vieira Júnior GM, Dutra LA, Ferreira PMP, Moraes MO, CostaLotufo LV, Pessoa C, Torres RB, Boralle N, Bolzani VS, Cavalheiro AJ. Cytotoxic clerodane diterpenes from Casearia rupestris. J Nat Prod 2011; 74: 776-781.

12. Militão GCG, Dantas INF, Ferreira PMP, Alves APNN, Chaves DC, Monte FJQ, Pessoa C, Moraes MO, Costa-Lotufo LV. In vitro and in vivo anticancer properties of cucurbitacin isolated from Cayaponia racemosa. Pharm Biol 2012; 50: 1479-1487.

13. Opie LH, Kowolik H. The discovery of captopril: from large animals to small molecules. Cardiovasc Res 1995; 30: 18-20.

14. Camargo AC, Ianzer D, Guerreiro JR, Serrano SM. Bradykininpotentiating peptides: beyond captopril. Toxicon 2012; 59: 516523.

15. Harvey AL. Toxins and drug discovery. Toxicon 2014; 92: 193200.

16. Pramuk JB. Phylogeny of South American Bufo (Anura: Bufonidae) inferred from combined evidence. Zool J Linn Soc 2006 146: 407-452.

17. Frost DR, Grant T, Faivovich J, Bain RH, Haas A, Haddad CFB, de Sá RO, Channing A, Wilkinson M, Donnellan SC, Raxworthy 
CJ, Campbell JA, Blotto BL, Moler P, Drewes RC, Nussbaum RA, Lynch JD, Green DM, Wheeler WC. The amphibian tree of life. Bull Am Mus Nat Hist 2006; 297: 1-370.

18. Gao H, Zehl M, Leitner A, Wu X, Zhimin W, Kopp B. Comparison of toad venoms from different Bufo species by HPLC and LCDAD -MS/MS. J Ethnopharmacol 2010; 131: 368-376.

19. Yang J, Zhang YH, Miao F, Zhou L, Sun W. Two new bufadienolides from the rhizomes of Helleborus thibetanus Franch. Fitoterapia 2010; 81: 636-639.

20. Ferreira PMP, Lima DJB, Debiasi BW, Soares BM, Machado KC, Noronha JC, Rodrigues DJ, Sinhorin AP, Pessoa C, Júnior GMV. Antiproliferative activity of Rhinella marina and Rhaebo guttatus venom extracts from Southern Amazon. Toxicon 2013; 72: 4351.

21. Puschett JB, Agunanne E, Uddin MN. Emerging role of the bufadienolides in cardiovascular and kidney diseases. Am J Kidney Dis 2010; 56: 359-370.

22. Cui X, Inagaki Y, Xu H, Wang D, Qi F, Kokudo N, Fang D, Tang W. Anti-hepatitis $\mathrm{B}$ virus activities of cinobufacini and its active components bufalin and cinobufagin in HepG2.2.15 cells. Biol Pharm Bull 2010; 33: 1728-1732.

23. Wang DL, Qi FH, Tang W, Wang FS. Chemical constituents and bioactivities of the skin of Bufo bufo gargarizans Cantor. Chem Biodivers 2011; 8: 559-567.

24. Delebinski CI, Georgi S, Kleinsimon S, Twardziok M, Kopp B, Melzig MF, Seifert G. Analysis of proliferation and apoptotic induction by 20 steroid glycosides in 143B osteosarcoma cells in vitro. Cell Prolif 2015; 48: 600-610.

25. Liu C, Cao W, Chen Y, Qu D, Zhou J. Comparison of toad skins Bufo bufo gargarizans Cantor from different regions for their active constituents content and cytotoxic activity on lung carcinoma cell lines. Pharmacogn Mag 2014; 10: 207-212.

26. Kai S, Lu JH, Hui PP, Zhao H. Pre-clinical evaluation of cinobufotalin as a potential anti-lung cancer agent. Biochem Biophys Res Commun 2014; 452: 768-774.

27. Gao H, Popescu R, Kopp B, Wang Z. Bufadienolides and their antitumor activity. Nat Prod Rep 2011; 28: 953-969.

28. Sciani JM, de-Sá-Júnior PL, Ferreira AK, Pereira A, Antoniazzi MM, Jared C, Pimenta DC. Cytotoxic and antiproliferative effects of crude amphibian skin secretions on breast tumor cells. Biomed Prev Nutr 2012; 1: 10-18.

29. Tempone AG, Pimenta DC, Lebrun I, Sartorelli P, Taniwaki NN, de Andrade HF Jr, Antoniazzi MM, Jared C. Antileishmanial and antitrypanosomal activity of bufadienolides isolated from the toad Rhinella jimi parotoid macrogland secretion. Toxicon 2008; 52: $13-21$

30. Guantai E, Chibale K. How can natural products serve as a viable source of lead compounds for the development of new/ novel anti-malarials?. Malar J 2011; 10 (suppl 1): S2.

31. Trager W, Jensen JB. Human malaria parasites in continuous culture. Science 1976; 193: 673-675.

32. Lambros C, Vanderberg J. Synchronization of Plasmodium falciparum erythrocytic stages in culture. J Parasitol 1979; 65: 418-420.

33. Denizot F, Lang R. Rapid colorimetric assay for cell growth and survival. Modifications to the tetrazolium dye procedure giving improved sensitivity and reliability. J Immunol Methods 1986; 89: 271-277.

34. Borenfreunda E, Babicha H, Martin-Alguacila N. Comparisons of two in vitro cytotoxicity assays-the neutral red (NR) and tetrazolium MTT tests. Toxicol in Vitro 1988; 2: 1-6.

35. do Céu de Madureira M, Paula-Martins A, Gomes M, Paiva J, Proença da Cunha A, do Rosário V. Antimalarial activity of medicinal plants used in traditional medicine in S. Tomé and Príncipe islands. J Ethnopharmacol 2002; 81: 23-29.

36. Bézivin C, Tomasi S, Lohézic-Le Dévéhat F, Boustie J. Cytotoxic activity of some lichen extracts on murine and human cancer cell lines. Phytomedicine 2003; 10: 499-503.

37. Pink R, Hudson A, Mouriès MA, Bendig M. Opportunities and challenges in antiparasitic drug discovery. Nat Rev Drug Discov 2005; 4: 727-740.

38. Dantas GR. Avaliação da atividade antimalárica de extratos obtidos de algas marinhas no litoral do Rio Grande do Norte. Dissertação (Mestrado em Ciências Biológicas), Universidade Federal do Rio Grande do Norte, Natal, RN. 2012. pp 1-72.

39. Ait-Mohamed O, Battisti V, Joliot V, Fritsch L, Pontis J, Medjkane S, Redeuilh C, Lamouri A, Fahy C, Rholam M, Atmani D, Ait-SiAli S. Acetonic extract of Buxus sempervirens induces cell cycle arrest, apoptosis and autophagy in breast cancer cells. PLoS One 2011; 6: e24537.

40. Cenzi G. Avaliação da atividade antimalárica e citotóxica de derivados de sulfonamidas e derivados 1,3,4-oxadiazólicos. Dissertação (Mestrado em Ciências da Saúde), Universidade Federal de São João Del Rei, Divinópolis, MG. 2013. pp 1-136. 